\title{
Physico-Chemical and Microbiological Properties of a Traditional Turkey Cheese Tomas/Serto (Dorak)
}

\author{
Ayşe Burcu Kurtulgan ${ }^{1}$ and Abdullah Dikici ${ }^{2}$ \\ 1. Department of Food Engineering, Faculty of Engineering, Tunceli University, Tunceli 62100, Turkey \\ 2. Department of Food Engineering, Faculty of Engineering, Usak University, Usak 64100, Turkey
}

\begin{abstract}
Turkey is a country producing various kinds of cheese. Tomas cheese is a kind of cheese that is still traditionally produced, and it is not widely-known. In this study, the characteristic properties of Tomas cheese, a local product that is extensively consumed in the city of Tunceli and its environs, have been examined. For this purpose, samples from cheese varieties currently on sale in the cities of Tunceli and Elazı $\breve{g}$ have been taken, and some of their physico-chemical and microbiological properties have been determined. The results of physico-chemical analysis showed that the average moisture rate of the samples was $53.24 \%$, average ash rate $4.24 \%$, average dry matter $46.76 \%$, average acidity rate in terms of lactic acid $1.08 \%$, average salt rate $2.93 \%$, average fat rate $17.66 \%$, average fat-free dry matter rate $25.56 \%$ and average $\mathrm{pH}$ value 4.67 . The microbiological analysis data showed that the average values for the total aerobic mesophyll bacteria (TAMB) was $7 \log _{10} \mathrm{kob} / \mathrm{g}, 2.3 \log _{10} \mathrm{kob} / \mathrm{g}$ for coliform, $4.6 \log _{10} \mathrm{kob} / \mathrm{g}$ for yeast, $5.5 \log _{10} \mathrm{kob} / \mathrm{g}$ for mold, $6.8 \log _{10} \mathrm{kob} / \mathrm{g}$ for Lactococcus spp., and $6.1 \log _{10} \mathrm{kob} / \mathrm{g}$ for Lactobacillus spp.. The results show the high variation among samples, proving that there has not been a standard production procedure. It has been established that the hygienic condition of the product changes according to the production process, and the probability for cross contamination is high. A large number of studies need to be carried out for this kind of traditional food items, due to lack of enough literature data in this paper.
\end{abstract}

Key words: Tomas/Serto (Dorak) cheese, traditional food, physico-chemical and microbiological properties.

\section{Introduction}

Cheese, which is an animal food, is a dairy product rich in proteins, fat, minerals and vitamins along with its rich calcium and phosphorus contents, and it has a very high nutritional value. The fact that it is easy to digest and its proteins contain all the basic aminoacids increases its importance in terms of nutrition and health [1]. Due to its importance, many varieties of cheese with different tastes and aromas are produced in Turkey and the world. Local varieties of cheese in many parts of Turkey are widely produced in usually family-run businesses and primitive dairy farms using traditional methods [2].

Tomas cheese is a local product that has a very important place in the city of Tunceli and its environs. It is also called "Serto" or "Dorak" in Tunceli. It is mostly made of sheep or goat milk, and its production

Corresponding author: Abdullah Dikici, Ph.D., research fields: food microbiology, dairy product and public healthy. usually starts in the months of May-June and continues until the months of September-October [3].

In accordance with the traditional production process, yoghurt is made from pasteurized milk first, and then the yoghurt is turned into ayran by adding water. Butter is produced by subjecting ayran to churning process. The remaining fat-free ayran is heated to boiling temperature to make çökelek (skim-milk cheese). After the heating process, ayran is curdled and fat-free çökelek is obtained. Then, çökelek is cooled, drained and filled into skin bags. Enough amounts of whole-fat milk, milk cream and yoghurt are added into the skin bag, and the mixture is mixed thoroughly at least once a week. This procedure is repeated for at least 3-4 months. Then, cheese is filled into skin bags and is left to mature in a cool place. Tomas cheese acquires its distinctive taste and aroma as a result of the physical, chemical and microbiological changes that occur during this 
maturing process [3]. In short, while the fat in yoghurt, which is used to make the cheese, is removed in the beginning, and fat is gradually increased during the maturing process of the cheese.

Researches show that, unlike other cheese varieties, Tomas cheese of Tunceli is made by fattening the cheese with yoghurt and milk cream. It also differs from the cheese made in other cities in terms of its ingredients and taste, because of both the milk used and the production technique. A standard production method specified for Tomas cheese does not exist in Turkey. Therefore, products of standard quality can not be produced. The fact that a control mechanism does not exist because it is produced in small family-run businesses, causes a low quality and reliability in cheese [4]. While a number of researches have been made on other cheese varieties, there are very few researches on Tomas cheese which is the subject of this research. Therefore, it is essential to increase the number of researches on Tomas cheese and make it possible for the production of healthy products of a standard quality. Thus, this study aimed to collect samples of Tomas/Serto (Dorak) cheese currently in the market in the cities of Tunceli and Elazığ and determine some of their physico-chemical and microbiological properties.

\section{Materials and Methods}

Samples of Tomas/Serto (Dorak) cheese were collected from the market in the cities of Tunceli and Elazığ, then put in sterilized glass jars and some physico-chemical and microbiological analyses have been conducted. Each analysis has been conducted by taking two samples. Samples have been preserved in refrigerator conditions $\left(4{ }^{\circ} \mathrm{C}\right)$.

\subsection{Microbiological Analyses}

A $10 \mathrm{~g}$ cheese sample and a $90 \mathrm{~mL}$ sterile $1 / 4$ ringer solution (Merck) were put into a stomacher bag and homogenized for $2 \mathrm{~min}$ in the blender under aseptic conditions. From this $10^{-1}$ dilution, dilutions of $10^{-2}$,
$10^{-3}, 10^{-4}, 10^{-5}, 10^{-6}, 10^{-7}$ and $10^{-8}$ were prepared in the tubes that contained $9 \mathrm{~mL} \mathrm{1/4} \mathrm{ringer} \mathrm{solution} \mathrm{[5].}$

2.1.1 Total Aerobic Mesophyll Bacteria (TAMB)

The number of TAMB was determined in plate count agar (PCA) medium with pour plate technique. The planted petris were incubated at $30 \pm 0.1{ }^{\circ} \mathrm{C}$ for $48 \mathrm{~h}[6]$.

2.1.2 Enumeration of Yeast and Mold

Planting was done in dichloran rose-bengal chloramphenicol (DRBC) agar with surface spreading method and incubated at $25 \pm 1{ }^{\circ} \mathrm{C}$ for $5 \mathrm{~d}$ in an aerob medium [7]. The bright and slightly disperse colonies that are round, oval or lemon-shaped were assumed to be yeast, and those that formed micella in various forms were considered to be mould [8].

\subsubsection{Enumeration of Coliforms}

It was performed in violet red bile (VRB) agar using the pour plate method, and after $24 \pm 2 \mathrm{~h}$ of incubation at $32 \pm 1{ }^{\circ} \mathrm{C}$, dark red colonies with a diameter of $0.5 \mathrm{~mm}$ were assumed to be coliform group [9].

2.1.4 Enumeration of Lactococcus spp.

It was performed by using M17 agar, and was determined by incubating it in an anaerob medium at $30{ }^{\circ} \mathrm{C}$ for $48 \mathrm{~h}[10,11]$.

2.1.5 Enumeration of Lactobacillus spp.

It was determined in De Man Rogosa and Sharpe (MRS) agar at $35 \pm 1{ }^{\circ} \mathrm{C}$ by incubating it in an anaerob medium [12].

\subsection{Chemical Analysis}

\subsubsection{Determination of Dry Matter}

Certain amount of cheese was dried at a temperature of $105{ }^{\circ} \mathrm{C}$ in a drying stove until its weight was unchanged. The percentage of dry matter was calculated gravimetrically from the difference in weight [13].

\subsubsection{Humidity Rate}

The humidity rate was calculated by subtracting the amount of dry matter. 


\subsubsection{Fat-Free Dry Matter Rate}

It was determined by subtracting the fat rate from dry matter rate.

\subsubsection{Titratable Acidity}

It was performed according to alkali titration method, and the results were expressed in terms of lactic acid percentage [14].

\section{$2.2 .5 \mathrm{pH}$}

The $10 \mathrm{~g}$ of grated cheese and $10 \mathrm{~mL}$ of pure water were mixed and homogenized, and then the $\mathrm{pH}$ values of the homogenized mixture were determined with a digital $\mathrm{pH}$ meter.

\subsubsection{Fat Amount}

It was determined with Gerber method by using Van-Gulik butyrometer [15].

\subsubsection{Salt Rate}

Salt rates were determined with Mohrtitration method according to the result of titration of the prepared sample with calibrated $0.1 \mathrm{~N} \mathrm{AgNO}_{3}$ [16].

\subsubsection{Ash Rate}

It was determined with gravimetric method according to the description by Yöney [17]. A certain amount of cheese is dried in porcelain containers, and after it was burned in an ash stove at a temperature of $550{ }^{\circ} \mathrm{C}$, the percentage of ash amount was calculated.

\section{Results and Discussion}

In this study, physico-chemical and microbiological analyses were conducted in order to identify some of characteristic properties of Tomas cheese collected from the cities of Elazığ and Tunceli, where it is consumed most in Turkey (Tables 1 and 2). Since it is a local product, there is the limited number of researches on Tomas or (Serto or Dorak) cheese as review of literature in doing this paper. Also, there are still not any standards regarding Tomas cheese. Therefore, standards for tulum cheese (TS 3001) issued by Turkish Standards Institute (TSE) were used in assessing and interpreting the results of the analyses obtained in the present research due to the similarity of Tomas cheese to tulum cheese [18].

\subsection{Microbiological Results}

TAMB value in Serto cheese varied between 6.0-7.7 $\log _{10} \mathrm{kob} / \mathrm{g}$ with the average $7 \log _{10} \mathrm{kob} / \mathrm{g}$. The number of TAMB plays an important role as an indicator in determining the microbiological quality of food [19]. As seen in Table 1, the number of the total microorganisms detected in the samples is quite high. In Ref. [20], the lowest numerical value of the total living bacteria in Thomas cheese was found to be $12 \times$ $10^{5} / \mathrm{g}$ and the highest $237 \times 10^{6} / \mathrm{g}$.

In the present research, the lowest total number of yeast and mould was $3 \log _{10} \mathrm{kob} / \mathrm{g}$ and the highest 6.2 $\log _{10} \mathrm{kob} / \mathrm{g}$. The average values were $4.6 \log _{10} \mathrm{kob} / \mathrm{g}$ and $5.5 \log _{10} \mathrm{kob} / \mathrm{g}$ for yeast and mould, respectively. The high numbers of yeast and mould in the research indicate that hygiene was not observed in the production of cheese. Also, the conditions of the environment, packing material and the way of cheese pressed into the packing material are also factors that influence the formation of mould in cheese [4]. Some mould types endanger human health by growing on the food item, where they inhabit and secreting mycotoxins. For these reasons, the total number of yeast and mould is an important criterion for food products [1].

The examined cheese samples contain various degrees of coliform bacteria (Table 1). Coliform microorganisms are indicators of bad sanitary conditions, insufficient or wrong pasteurization practices, repetition of contamination after cooking or pasteurization [21, 22].

The value of Lactococcus spp. microorganisms in Tomas cheese varied between 4.4-7.4 $\log _{10} \mathrm{kob} / \mathrm{g}$ with the average $6.8 \log _{10} \mathrm{kob} / \mathrm{g}$. While the value of Lactobacillus spp. microorganisms in the examined cheese samples varied between 4.0-6.7 $\log _{10} \mathrm{kob} / \mathrm{g}$ with the average $6.1 \log _{10} \mathrm{kob} / \mathrm{g}$. 
Table 1 The results of the microbiological analysis of Tomas (Serto or Dorak) cheese.

\begin{tabular}{llll}
\hline \multirow{2}{*}{ Bacteria } & \multicolumn{2}{c}{ Numbers of microorganism $\left(\log _{10} \mathrm{kob} / \mathrm{g}\right)$} \\
\cline { 2 - 4 } & Minimum & Maximum & Average \\
\hline Total aerobic mesophilic bacteria (TAMB) & 6.0 & 7.7 & 7.0 \\
Yeast & 4.2 & 6.2 & 4.6 \\
Mold & 3.0 & 5.0 & 5.5 \\
Coliform & $<3.0$ & 3.0 & 2.3 \\
Lactococcus spp. & 4.4 & 7.4 & 6.8 \\
Lactobacillus spp. & 4.0 & 6.7 & 6.1 \\
\hline
\end{tabular}

Table 2 The results of the physico-chemical analysis of Tomas (Serto or Dorak) cheese.

\begin{tabular}{llll}
\hline Physico-chemical properties & Minimum & Maximum & Average \\
\hline $\mathrm{pH}$ & 3.84 & 5.05 & 4.67 \\
Titratable acidity (\% lactic acid) & 0.86 & 1.30 & 1.08 \\
Dry matter (\%) & 44.19 & 51.11 & 46.76 \\
Moisture (\%) & 48.89 & 55.81 & 53.24 \\
Non-fat dry matter (\%) & 20.12 & 42.16 & 25.56 \\
Fat (\%) & 10.00 & 27.00 & 17.66 \\
Salt rate (\%) & 2.11 & 3.51 & 2.93 \\
Ash rate (\%) & 1.44 & 5.58 & 4.24 \\
\hline
\end{tabular}

\subsection{Physico-Chemical Properties}

The dry matter rate of the collected samples in the present study showed a variation between $44.19 \%$ and $51.11 \%$, and the average value was found to be $46.76 \%$ (Table 2). As the amount of dry matter increases in cheese, meaning the components other than water, i.e., nutritional components, its nutritional value increases, too [23]. The amount of dry matter may show variation depending on such factors as the way cheese made, its type, its degree of maturity, the quality of milk, etc..

It was stated that the rate of humidity must be $40 \%$ at most according to Tulum cheese standards (TS 3001). In the light of this, the required amount of dry matter should be $60 \%$, but the amount of dry matter in the samples observed in this study was found to be below $60 \%$. Therefore, samples did not comply with TS 3001 standards. Doğan and Tükel [19] showed that the rate of dry matter in Thomas cheese was found to be $35.54 \%$ at least, $62-33 \%$ at most and $47.49 \%$ on average.

The rate of humidity in Tomas cheese varied between $48.89 \%$ and $55.81 \%$ with the average $53.24 \%$ (Table 2). Doğan and Tükel [19] found the rate of humidity in Tomas cheese to be varying between $37.54 \%$ and $64.46 \%$ with $52.51 \%$ on average. The data in this study are similar to the results obtained by Doğan and Tükel [19]. These values always in a wide interval are the most important evidence showing lack of a standard production of these cheeses.

The fat rate in the examined samples showed a wide range of variation between $10 \%$ and $27 \%$, and the average value was found to be $17.66 \%$ (Table 2). The cheeses were made from different milk sources and different processing methods, so the fat rates were different. Doğan and Tükel [19] determined that the fat rate in Tomas cheese varied between $5 \%$ and $35.50 \%$ and the average value was $18.13 \%$.

Titration acidity (in terms of \% lactic acid) in Tomas cheese varied between $0.86 \%$ and $1.3 \%$, and the average value was $1.08 \%$ (Table 2). According to TS 3001, the Tulum cheese with lactic acid of $1.5 \%$ at most is evaluated as the first class and $2.5 \%$ as the second class. In the light of this, the values of lactic acid in the samples below $1.5 \%$ were determined to be the first class cheese.

The $\mathrm{pH}$ values in the examined samples varied between 3.84 and 5.05, and the average value was 
4.67 (Table 2). It was observed by Doğan and Tükel [19] that the acidity in Tomas cheese varied between $64^{\circ}$ and $184^{\circ}$ in terms of Soxhlet-Henkel ( $\left.{ }^{\circ} \mathrm{SH}\right)$ and the average value was $102.5^{\circ}$.

The salt values in the examined samples varied between $2.11 \%$ and $3.51 \%$ and the average value was found to be $2.93 \%$ (Table 2). Salt content regulates the aroma, color and composition, enables the removal of excess water by adjusting the amount of humidity, regulates maturity by controlling the starter bacteria and the activities of some unwanted microorganisms, and increases the durability of the cheese [1, 19]. Doğan and Tükel [19] measured the salt rate in Tomas cheese of $1.87 \%$ at least, $4.68 \%$ at most and $3.05 \%$ on average.

The ash values were seen to vary between $1.44 \%$ and $5.58 \%$ and the average value was determined to be $4.24 \%$ (Table 2). Doğan and Tükel [19] found that ash rate varied between $2.08 \%$ and $5.00 \%$ and the average value was $3.42 \%$.

\section{Conclusions}

Microflora values and physico-chemical values obtained in the present study and similar studies were observed to be quite different from each other. There is a wide gap between the maximum and minimum values. The difference observed in these results is thought to be lack of a standard production method for local products and that families employ different methods of production under different conditions. This, in turn, influences the quality and reliability of cheese negatively and causes economic losses. Therefore, production technologies of local products, such as Tomas (Serto or Dorak) cheese, must be modernized, proper packaging material must be chosen and care must be taken to prevent subsequent contamination and carry out production under hygienic conditions to obtain products of a standard quality. Control mechanism must be run effectively. Further scientific studies are needed in this area.

\section{References}

[1] Yildiz, F. 2003. "Determination of Microbiological, Chemical and Organoleptic Properties of Urfa Cheese Sold in Ankara Market.” Master thesis, Graduate School of Natural and Applied Sciences, Ankara University, Ankara. (in Turkish)

[2] Sert, D., and Ve Akin, N. 2008. "Traditional Production Methods of Some Important Tulum Cheese Varieties in Turkey." In Proceedings of the 10th Turkey Food Congress, 717. (in Turkish)

[3] Kamber, U. 2005. Traditional Anatolian Cheese. Ankara: Miki Publisher, 102-3. (in Turkish)

[4] Gündüz, H. H. 1982. "Tomas Cheese: Part I, the Microflora of Tomas Cheese." The Journal of Food 7 (5): 227-30. (in Turkish)

[5] Turkish Standardization Institute. 2004. "Microbiology of the Food Chain-Horizontal Method for the Enumeration of Microorganisms: Colony Count at $30^{\circ} \mathrm{C}$ by the Pour Plate Technique." TS EN ISO 4833-1, Turkish Standardization Institute, Ankara. (in Turkish)

[6] Collins, C. H., and Lyne, P. M. 1984. Microbiological Methods. London: Butterworth \& Co. Publisher Ltd., 450.

[7] Tournas, V., Stack, M. E., Mislivec, P. B., Koch, H. A., and Bandler, R. 2001. "Yeasts, Molds and Mycotoxins." In Bacteriological Analytical Manual. United States of America: Food and Drug Administration.

[8] Temiz, A. 1996. General Microbiology Application Techniques. Ankara: Hatipoğlu Publisher, 274. (in Turkish)

[9] Koburger, J. A., and Marth, E. H. 1984. "Yeasts and Moulds." In Compendium of Methods for the Examination of Foods, edited by Speck, M. L. Washington, DC: American Public Health Association, 197-202.

[10] Corroler, D., Manguin, İ., Desmasures, N., and Gueguen, M. 1998. "An Ecological Study of Lactococci Isolated from Raw Milk in the Cammambert Cheese Registered Designation of Origin Area." Appl. Environ. Microbiol. 64 (12): 4729-35.

[11] Dağdemir, E. 2006. "Identification of Lactic Acid Bacteria Isolated from Pickled White Cheese and Cultivation Possibilities of Selected Some Isolates." Ph.D. thesis, Graduate School of Natural and Applied Sciences, Atatürk University, Erzurum. (in Turkish)

[12] Birollo, G. A., Reinheimer, J. A., and Vindarola, C. G. 2000. "Viability of Lactic Acid Microflora in Different Types of Yoghurt." Food Research International 33 (9): 799-805.

[13] Turkish Standardization Institute. 2008. "Cheese and Processed Cheese-Total Solids Determination (Reference Method)." TS EN ISO 5534, Turkish 
Standardization Institute, Ankara. (in Turkish)

[14] Turkish Standardization Institute. 2013. "White Cheese." TS 591, Turkish Standardization Institute, Ankara. (in Turkish)

[15] Turkish Standardization Institute. 2015. "Cheese-Determination of Fat Content (Van Gulik Method)." TS ISO 3433, Turkish Standardization Institute, Ankara. (in Turkish)

[16] Ministry of Agriculture Forestry and Rural Affairs. 1983. Food Inspection and Analysis Methods. Ankara: T.C. Ministry of Agriculture Forestry and Rural Affairs, 795. (in Turkish)

[17] Yöney, Z. 1973. Inspection and Analysis Methods of Milk and Milk Products. Ankara: Ankara University, Agricultural Faculty, 182. (in Turkish)

[18] Turkish Standardization Institute. 2006. "Tulum Cheese." TS-3001-2006, Turkish Standardization Institute, Ankara. (in Turkish)
[19] Doğan, H. B., and Tükel, Ç. 2000. "Total (Aerobic Mesophilic) Bacteria.” In Food Microbiology and Applications. Ankara: Food Engineering Department, Ankara University, 323-8. (in Turkish)

[20] Kurt, A., Gündüz, H. H., and Demirci, M. 1979. "Research on Tomas Cheese." Journal of the Faculty of Agriculture 10: 37-49. (in Turkish)

[21] Çakir, İ. 2000. "Coliform Bacteria and E. Coli." In Food Microbiology and Applications. Ankara: Food Engineering Department, Ankara University, 335-44. (in Turkish)

[22] Kıvanç, M. 1989. "Microbial Flora of Kashar Cheese, Sold in Erzurum Market." Food 16 (5): 23-30. (in Turkish)

[23] Kurt, A., Çakmakçı, S., Çağlar, A., and Ve Akyüz, N. 1991. "A Study on the Composition, Sensory, Physical and Chemical Properties of Erzincan Tulum (Şavak) Cheese." Food 16 (5): 295-302. (in Turkish) 